\title{
Oblicza patriotyzmu. Kilka uwag i wniosków z badania studentów
}

\section{The faces of patriotism. Remarks and conclusions from research on students}

\section{Streszczenie:}

W literaturze oraz publicystyce istnieją spory dotyczące znaczenia i sensu patriotyzmu we współczesnym świecie. Podkreśla się przy tym jego zmieniające się oblicza oraz nowe formy. W poniższym artykule zaprezentowano wyniki badania ankietowego zrealizowanego wśród studentów pedagogiki trzech uczelni. Celem badania było poznanie sposobów rozumienia i akceptacji różnych form patriotyzmu w demokratycznej i pluralistycznej rzeczywistości społecznej. Najwyższy poziom aprobaty wśród badanych uzyskały tzw. „stare formy patriotyzmu”, które można nazwać również patriotyzmem symbolicznym.

Słowa kluczowe: młodzież akademicka, patriotyzm, nacjonalizm, pluralizm

\begin{abstract}
:
Ongoing disputes on the meaning and sense of patriotism in the modern world are reflected in literature and journalism. The varying faces and new forms of patriotism are being emphasized. The article presents the results of a survey conducted among pedagogy students of three universities. The aim of the research was recognition of the ways of understanding and accepting various forms of patriotism in the democratic and pluralistic social reality. The highest level of approval among the respondents was obtained by the so-called "old forms of patriotism", which might also be referred to as symbolic patriotism.
\end{abstract}

Keywords: academic youth, patriotism, nationalism, pluralism 
Błażej Przybylski - Oblicza patriotyzmu. Kilka uwag...

\section{Wprowadzenie}

Patriotyzm należy uznać za zjawisko ze wszech miar pozytywne i wskazane. Wątpliwości budzi to, co obserwujemy we współczesnej Polsce, czyli jego utożsamianie z postawami przepełnionymi wrogością i niechęcią do innych. Nierzadko zdarza się, że patriotyzm jest identyfikowany z poglądami ksenofobicznymi i szowinistycznymi. Co więcej, patriotyzm dziś stanowi narzędzie przemocy symbolicznej. Jest on bowiem - w sferze publicznej - zarezerwowany przede wszystkim dla młodzieży o poglądach prawicowych i radykalnych. To w kontekście ruchów młodzieżowych odwołujących się do spuścizny i tradycji ONR i Romana Dmowskiego słyszymy, że jest to tzw. młodzież patriotyczna. Przy opisie demonstrantów w obronie konstytucji czy uczestników tzw. „marszów równości” raczej nie można spotkać się z podobnymi sformułowaniami. Niektórzy partyjni liderzy za to, mówiąc o swoim zapleczu, określają go mianem „obozu patriotycznego”, jednocześnie subtelnie dając do zrozumienia, że polityczni przeciwnicy patriotami już nie są. Patriotyzm dziś, jak widzimy, został skutecznie przywłaszczony przez jedną ze stron politycznych sporów. Prowadzić to będzie moim zdaniem - do jeszcze większej deprecjacji znaczenia terminu.

Patriotyzm ma mieć zawsze pozytywny, przyjazny, otwarty charakter. Jak pięknie napisał Jan Józef Lipski - autor niezwykle mądrego i inspirującego tekstu Dwie ojczyzny i dwa patriotyzmy:

Sądzę, że szowinizm, megalomania narodowa, ksenofobia, czyli nienawiść do wszystkiego co obce, egoizm narodowy - nie dadzą się pogodzić z nakazem chrześcijańskim miłości bliźniego. Patriotyzm natomiast - daje się pogodzić. Tak jak szczególna miłość w rodzinie nie musi i nie powinna być przeszkodą dla miłości bliźniego - tak i szczególna miłość dla członków tej samej wspólnoty narodowej winna być podporządkowana tej samej nadrzędnej normie moralnej. Patriotyzm jest z miłości - i do miłości ma prowadzić, jakakolwiek inna jego forma jest deformacją etyczną ${ }^{1}$.

1 J. J. Lipski, Dwie ojczyzny, dwa patriotyzmy. Rzecz o megalomanii narodowej i ksenofobii Polaków, Warszawa 1992, s. 14. 
Nadal we współczesnej Polsce różnorakie „deformacje etyczne” obecne są w przestrzeni publicznej, a tzw. „środowiska patriotyczne” przedstawiane są przez wielu jako ostatni obrońcy i pierwsi krzewiciele patriotyzmu. Środowiska te przekazują i utrwalają wizję Polski otoczonej przez samych wrogów czyhających tylko na jej upadek oraz że same - w czasach zaniku wartości i słabnącego przywiązania do ojczyzny - stanowią wzór cnót moralnych. Oczywiście obraz ten nie tylko jest fałszywy, ale także oparty na wartościach i emocjach stojących w sprzeczności z patriotyzmem rozumianym w duchu Jana Józefa Lipskiego. Patriotyzmu bowiem nie można łączyć z nienawiścią, wrogością, wykluczaniem innych ze względu na odmienność w myśleniu, działaniu czy stylu życia. Pytaniem, które stale przewija się w debatach publicznych, jest to dotyczące pożądanego oblicza i znaczenia patriotyzmu w życiu współczesnych obywateli i narodów. Jak dodawał cytowany przeze mnie autor: „walka o kształt polskiego patriotyzmu będzie rozstrzygająca dla losów naszego narodu - dla losów moralnych, kulturalnych, politycznych"2.

\section{Studenckie inspiracje}

Sam pomysł realizacji badania dotyczącego patriotyzmu, precyzyjniej mówiąc sposobu jego postrzegania, związany jest bezpośrednio z prowadzonymi przeze mnie zajęciami ze studentami pedagogiki. Cyklicznie, co rocznie, na listopadowych ćwiczeniach staram się rozmawiać ze studentami o obliczach współczesnego patriotyzmu. Czas tych rozmów nie jest przypadkowy. To czas świętowania przez Polaków odzyskanej niepodległości; czas, w którym w mediach wiele miejsca poświęca się problematyce postaw wobec ojczyzny; wreszcie czas, w którym tradycyjnie od kilku lat dyskutuje się na temat transparentów i okrzyków pojawiających się na tzw. „Marszach Niepodległości”. Za każdym razem tytularne hasło Marszu różni się. Zawsze ma jednak ono charakter niepozostawiający złudzeń co do preferencji ideologicznych

2 Ibidem, s. 17. 
Błażej Przybylski - Oblicza patriotyzmu. Kilka uwag...

organizatorów oraz ich wizji „patriotyzmu”. Przykładowo w roku 2017 hasło brzmiało „Polska dla Polaków - Polacy dla Polski”, zaś w roku 2018: „Bóg. Honor. Ojczyzna”. W imprezie tej od lat bierze udział - szacunkowo - co najmniej kilkadziesiąt tysięcy osób z całej Polski. Dzień Niepodległości, a przede wszystkim cała jego otoczka, wydaje się dobrym przyczynkiem do rozmowy ze studentami o, najogólniej mówiąc, patriotyzmie. Przy okazji tych rozmów, wśród studentek - pedagogika to kierunek wyraźnie sfeminizowany - zauważam przynajmniej trzy tendencje.

Po pierwsze, dyskusje te wzmocniły we mnie przekonanie, iż nadal dominuje interpretowanie patriotyzmu jako postawy obronnej i wartości uroczystej, która przejawia się w okazywaniu uczucia w czasach zagrożenia pokoju i niepodległości. Rozmowy te, toczone są przecież w XXI wieku, kiedy to Polska znajduje się w sercu Europy nie tylko w aspekcie geograficznym, ale też symbolicznym; należymy bowiem do najważniejszych i najsilniejszych sojuszy światowych: NATO oraz UE. Polacy mają możliwości podróżowania, poznawania świata, doświadczania jego różnorodności. Indywidualne aspiracje są urzeczywistniane na wielu płaszczyznach życia jednostkowego i grupowego. Studenci mogą wybierać dowolne kierunki studiów i zajmować się pogłębianiem własnych pasji i zainteresowań. Perspektywy zawodowe studentów, mimo iż nie tak optymistyczne, jak zakładano wcześniej, to jednak dają nadzieję na satysfakcjonującą przyszłość. Na horyzoncie nie widać zagrożeń militarnych, głodu, utraty wolności i suwerenności czy innych niebezpieczeństw w skali makro. Nawet jeśli część obserwatorów życia politycznego uważa, że polska demokracja jest zagrożona, to jeszcze nie powód, by rozpaczać, rozkładać ręce z bezradności i pogrążać się w poczuciu beznadziei i braku jakichkolwiek nadziei na lepsze jutro. Być może jest to właśnie szansa na realizację patriotycznego obowiązku, za jaki może uchodzić walka o demokratyczną Rzeczpospolitą.

Mimo stosunkowo pozytywnej sytuacji geopolitycznej studenci w rozmowach prowadzonych na zajęciach nadal wskazują na np. gotowość oddania życia za ojczyznę jako podstawowy wyraz patriotyzmu. 
Ta niespójność między ich wizją patriotyzmu a współczesną rzeczywistością, jakże odmienną od minionej, stanowiła kluczową motywację do szerszego rozpoznania znaczeń nadawanych patriotyzmowi. O zmieniających się obliczach patriotyzmu pisał chociażby Władysław Bartoszewski, podkreślając, że:

„patriotyzm jest jeden, tak jak uczciwość jest jedna, honor jest jeden - tylko sprawdza się w inny sposób. Wystawiony jest na inne próby i ma inne aspekty praktyczne w warunkach trudnych i w warunkach łatwych"3.

W literaturze socjologicznej i pedagogicznej można jednak spotkać się z wieloma rodzajami patriotyzmu, wśród których wymienia się m.in. „patriotyzm ekstremalny” i „patriotyzm umiarkowany” lub też „patriotyzm demokratyczny” $i$ „patriotyzm autorytarny” - wszystkie te podziały odnoszą się do różnych przejawów i form naszego stosunku do kraju4.

Obecne warunki, zgodnie z podziałem zaproponowanym przez Bartoszewskiego, zaliczyć powinniśmy do tych nazwanych „łatwymi”. W kontekście definiowania i wyrażania patriotyzmu wydaje się, że przede wszystkim są one jednak inne. $W$ pewnym wymiarze być może nawet trudniejsze. Kiedyś bowiem istniał konsensus co do znaczenia patriotyzmu i uznawanych, pożądanych sposobów jego wyrażania. Obecnie istnieją wątpliwości i dylematy co do jego treści i wymiaru dla życia jednostkowego i wspólnotowego. Należy zgodzić się ze stanowiskiem Zbigniewa Kwiecińskiego, iż:

po odzyskaniu niepodległości i uwolnieniu się od dominacji wielkiego sąsiada patriotyzm stał się pustym hasłem, na którym próżno próbuje się budować system nowych zaangażowań 5 .

${ }^{3}$ W. Bartoszewski, Patriotyzm czasu wojny i pokoju, [w:] A. Kozłowska (red.), Patriotyzm polski jaki jest? Jaki winien być?, Warszawa 2001, s. 14.

${ }^{4}$ M. Zembylas, The Teaching of Patriotism and Human Rights: An uneasy entanglement and the contribution of critical pedagogy, "Educational Philosophy and Theory" 2014, nr 10 (46), s. 1145.

5 Z. Kwieciński, Edukacja wobec wyzwań demokracji, [w:] Z. Kwieciński, Tropy ślady - próby, Poznań Toruń 2000, s. 75. 
Błażej Przybylski - Oblicza patriotyzmu. Kilka uwag...

Marcin Król dodaje z kolei, wskazując na rosnące znaczenie patriotyzmu w wymiarze indywidualnym, że:

nie jest w dzisiejszym świecie tak, że ojczyzna wymaga od nas postaw patriotycznych. Wymagania naszej duchowej tożsamości powodują, że musimy być patriotami, jeżeli chcemy zachować swoje życie wewnętrzne. Dochodzi zatem do odwrócenia tradycyjnego rozumowania6.

Po drugie, do pojawiających się haseł, często o charakterze wybitnie ksenofobicznym i nacjonalistycznym, większość studentów podchodziła w sposób bardzo neutralny, obojętny. Nie wykazywała ona oznak sprzeciwu, buntu czy też braku aprobaty dla przemarszu przez stolicę rówieśników z transparentami wzywającymi do eliminacji mniejszości etnicznych, seksualnych czy religijnych. Jednocześnie też przyznaję, że - w trakcie rozmów prowadzonych na zajęciach - studenci podchodzili do haseł i wizji głoszonych przez organizatorów Marszu Niepodległości bez większego entuzjazmu i ekscytacji. Przede wszystkim na przestrzeni ostatnich lat zaobserwowałem brak zainteresowania i zaangażowania studentów wokół problematyki społecznej, w tym też szerzącej się mowy nienawiści. Refleksja ta całkowicie tożsama jest z wynikami badań nad aktywnością publiczną młodzieży, które wyraźnie podkreślają polityczną bierność i apatię zdecydowanej większości przedstawicieli młodego pokolenia. Zaznaczam, że poniżej przedstawione wyniki badania nie dotyczą poziomu natężenia konkretnych postaw względem ojczyzny ani stopnia akceptacji wobec haseł pojawiających się w przestrzeni publicznej w dniu tak ważnym dla Polaków, jakim jest 11 listopada.

Po trzecie, wśród nielicznej grupy studentów widoczne były opinie pełne dezaprobaty, negacji, a nawet niechęci wobec patriotyzmu. Przyczyna tego tkwi w zbiorowej identyfikacji patriotyzmu $\mathrm{z}$ określonym zestawem poglądów i postaw, z całym „imaginarium” społecznym odnoszącym się do patriotyzmu. Dziś patriotyzm przez wielu zostaje utożsamiany z młodzieżą radykalną, przepełnioną nienawiścią i ksenofobią. Zaś osoby noszące tzw. „tatuaże patriotyczne” i „odzież patrio-

\footnotetext{
${ }^{6}$ M. Król, Patriotyzm przyszłości, Warszawa 2004, s. 95.
} 
tyczną" kojarzą nam się z wyrostkami terroryzującymi okolicę, młodymi mężczyznami z tatuażami np. „Polski Walczącej” chodzącymi bez koszulek po ulicy i głośno komentującymi, w sposób niecenzuralny, wygląd przechodniów czy też stadionowymi zadymiarzami z zasłoniętymi szalikami z napisem „White Patriots”, wykrzykującymi hasła „Bóg. Honor. Ojczyzna”. „Patriotyzm” kojarzyć się może też z niechęcią wobec Unii Europejskiej i wszelkich mniejszości, podpalaniem tęczy, atakowaniem „lewaków”, Arabów i antysemityzmem. Przeniesiony zostaje obraz znany z mediów i obserwowany na ulicach większych miast, i mylnie utożsamiany z „patriotyzmem”, na jego postrzeganie, rozumienie i ogólną ocenę. Za takim ulicznym „patriotyzmem” kryją się wartości całkowicie sprzeczne $\mathrm{z}$ humanizmem, demokracją, cywilizacją Zachodu, nowoczesnością. Nie dziwi zatem dezaprobata wobec tego wymiaru „patriotyzmu”. Jan Józef Lipski pisał:

trzeba tu wyraźnie i jasno powiedzieć: nie zawsze możliwy jest dialog; często sama próba podjęcia go bywa hańbą (jeśli nie jest zwykłą głupotą). Z bohaterami antysemickich wybryków w „marcowej” prasie dialogu być nie może - ani z tymi, którzy widzą w tej brudnej publicystyce wyraz swych przekonań. Nie mamy z nimi wspólnej ojczyzny ani nie chcemy z nimi mieć w ogóle nic wspólnego ${ }^{7}$.

We współczesnej Polsce obecne są środowiska, od których należy trzymać się z daleka i z którymi rozmawiać nie należy. Jak przed laty pisał Władysław Bartoszewski, w życiu przede wszystkim „warto być przyzwoitym".

W podobnym tonie wypowiada się Marcin Król:

„najbardziej niebezpieczna jest tolerancja fałszywa, czyli nie tylko zgoda na istnienie innych poglądów niż moje, ale także poczucie, że powinienem starać się zrozumieć te poglądy, zrozumieć intencje ludzi, którzy je głoszą, czyli w sumie po części je akceptować, tak jak akceptuje się istnienie wielu kwiatów. Otóż takie błędne pojmowanie tolerancji zaciemnia nam obraz nowoczesnego liberalnego patriotyzmu. Natychmiast bowiem zwycięzcami w patriotycznym kon-

\footnotetext{
7 J. J. Lipski, Dwa patriotyzmy..., op. cit., s. 17.
} 
Błażej Przybylski - Oblicza patriotyzmu. Kilka uwag...

kursie okazują się ci, którzy głośno domagają się prawa do bycia prawdziwymi patriotami" 8 .

Odrębną, aczkolwiek niezwykle ważną i aktualną kwestią jest znaczenie formalnej edukacji w procesach kształtowania i wzmacniania patriotyzmu. Problematyka ta ujęta może być w tak ogólnym pytaniu, jak „czy szkoła w ogóle powinna uczyć patriotyzmu?”. W przypadku pozytywnej odpowiedzi dalej pojawiają się kolejne pytania: „jaki to ma być patriotyzm (czym jest „właściwy” patriotyzm?), „do czego ma on prowadzić, ,,jaki ma być program edukacji patriotycznej” 9 . Wyzwaniem stojącym przed wszystkimi zainteresowanymi kształtowaniem postaw obywatelskich, otwartości i zaangażowania w życiu społeczne jest odzyskanie patriotyzmu. Odzyskanie patriotyzmu jako postawy przyjaznej, otwartej, przepełnionej empatią i pozytywnymi emocjami a pozbawionej nienawiści, wrogości i pogardy. Nie można patriotyzmu zostawiać prawicowym radykałom.

Powyższe uwagi podkreślają różnorodność myślenia o patriotyzmie, wielokierunkowość podejść i wielość interpretacji znaczenia patriotyzmu w nowoczesnym świecie oraz brak pełnej zgody co do ogólnej oceny zjawiska i rozmywanie się pozytywnego wydźwięku terminu, co jest spowodowane w głównym mierze jego zawłaszczaniem przez radykalnie prawicowe środowiska.

\section{Procedura badawcza}

Ta część artykułu stanowić będzie „quasi-raport” z krótkiego badania dotyczącego rozumienia patriotyzmu wśród młodzieży studiującej pedagogikę. Dokonam w niej, na podstawie otrzymanych wyników, systematyzacji współczesnego rozumienia patriotyzmu przez młodzież akademicką. Celem badania było poznanie opinii młodzieży akademickiej na temat znaczenia współczesnego patriotyzmu; przede wszyst-

\footnotetext{
${ }^{8}$ M. Król, Patriotyzm przyszłości..., op. cit., s. 112.

9 J. White, Patriotism without Obligations, "Journal of Philosophy of Education" 2001, nr 1(35), s. 141-142.
} 
kim interesował mnie poziom akceptacji wybranych form patriotyzmu. Badanie miało dać odpowiedź na pytanie: czym jest patriotyzm dla badanych studentów?

Badanie to zostało zrealizowane w okresie od maja do czerwca 2017 roku na próbie 158 studentów studiów dziennych (47\%) i niestacjonarnych (53\%), mieszczących się w przedziale wiekowym 18-26 lat. Badanymi były w przeważającej większości kobiety (97\%). Zdecydowana większość badanych (81\%) nie potrafiła określić swoich poglądów politycznych. Rozkład osób deklarujących się jako prawicowe (7\%), centrowe (6\%) i lewicowe (5\%) jest równomierny.

Narzędziem badawczym był krótki kwestionariusz ankiety skonstruowany na bazie kwestionariuszy stosowanych przez renomowane ośrodki badawcze (np. CBOS). Kwestionariusz składał się z 8 zamkniętych pytań. Został on rozdany studentom na trzech uczelniach: w Warszawie $(\mathrm{N}=50)$, Toruniu $(\mathrm{N}=42)$ oraz Gdańsku $(\mathrm{N}=66)$. Badanie miało charakter ćwiczeniowy i eksploracyjny - wyników nie można uogólniać na całą populację studentów ani nawet na konkretną uczelnię i kierunek. Własne doświadczania uczelnianych rozmów zamierzałem porównać z szerszym, ilościowym odczytaniem zachowań stanowiących w oczach studentów przejaw patriotyzmu. $Z$ racji specyfiki badań ankietowych mających charakter deklaratywny oraz stosunkowo powierzchowny - jeśli chodzi o zrozumienie istoty patriotyzmu i znaczeń nadawanych konkretnym czynnościom podejmowanym przez obywateli - zadowolić się muszę jedynie studenckimi opiniami niepotwierdzonymi wnikliwszymi analizami empirycznymi. Studenci zostali poproszeni o ustosunkowanie się do dziewiętnastu twierdzeń stanowiących potencjalne znaczenie patriotyzmu (19 form patriotyzmu).

\section{Wyniki - interpretacja i komentarz}

Interesowały mnie przede wszystkim formy, jakie zdaniem studentów przybiera patriotyzm, inaczej mówiąc, na czym on ich zdaniem dziś polega. Największy poziom aprobaty wśród studentów uzyskują 
Błażej Przybylski - Oblicza patriotyzmu. Kilka uwag...

„stare” formy patriotyzmu, które można by określić mianem symbolicznych. Prawie 100\% (w tym 86\% zdecydowanie) zgadza się, że patriotyzm polega na okazywaniu szacunku godłu, fladze i hymnowi państwowemu. Następne na liście popularności sformułowanie cieszy się prawie o 20 punktów procentowych mniejszym „silnym poziomem akceptacji”. Pielęgnowanie polskich tradycji to forma, z którą zgadza się również niemalże 100\% badanych, ale „tylko" 67\% zdecydowanie się zgadza. Z odpowiedzią „dbanie o kulturę polską” zgadza się ponad 95\% badanych. Te trzy formy patriotyzmu cieszą się największą akceptacją. Wszystkie one, można powiedzieć, wpisują się w „konserwatywne” myślenie o patriotyzmie i obowiązkach każdego patrioty. Ten konserwatywny wymiar patriotyzmu, związany z pielęgnowaniem „polskości” w wymiarze symbolicznym, stanowi najsilniejsze wyobrażenie badanych studentów o patriotyzmie.

Inny wymiar, stanowiący prawdopodobnie archetyp polskiego myślenia o patriotyzmie, cieszy się również wysoką aprobatą. Ponad 80\% badanych zgadza się bowiem, że patriotyzm przejawia się w gotowości do walki lub oddania życia za ojczyznę (40\% zdecydowanie zgadza się, a 41\% raczej zgadza się). Militarny aspekt patriotyzmu dziś na pewno jest słabiej odczuwalny, gdyż żyjemy w czasach względnie spokojnych i stabilnych. Niektórzy nawet wskazują, że patriotyzm może dziś być jedynie wartością uroczystą - która aktywizuje się w czasach zagrożenia niepodległości i suwerenności ${ }^{10}$. Wtedy to walka za ojczyznę stanowi kluczowy wyznacznik patriotyzmu. Nadal znaczna część badanych wskazuje, że poświęcenie w myśl zasady „pięknie i zaszczytnie jest umierać za ojczyznę" to przejaw patriotyzmu w najczystszej formie. Z rozmów przeprowadzonych ze studentami wynika, że patriotyzm nadal jawi się jako gotowość do poświęceń, w tym także tego ostatecznego. Prawdopodobnie jest to konsekwencją przede wszystkim szkolnej edukacji i dominującej formuły „edukacji patriotycznej”, która koncentruje się na wymiarze historycznym i pielęgnuje mesjanistyczną wizję narodu.

10 M. J. Szymański, Socjologia edukacji. Zarys problematyki, Warszawa 2013, s. 150. 
Zdecydowana większość badanych, prawie $90 \%$ (w tym $62 \%$ zdecydowanie), zgadza się, że patriotyzm to dbałość o wychowanie dzieci. Tak wysoki poziom akceptacji dla tego twierdzenia wśród badanych nie dziwi. Studenci pedagogiki w przyszłości w dużej części będą właśnie zajmować się kształtowaniem przyszłych pokoleń młodych Polaków. Ciekawe, czy wybrany wykonywany zawód identyfikować będą z realizacją patriotycznego obowiązku, powołania. Znacznie mniejszy odsetek $(60 \%)$ utożsamia patriotyzm $\mathbf{z}$ wypełnianiem obowiązków zawodowych.

Patriotyzm dzisiejszy musi różnić się od tego wczorajszego, gdyż cała sytuacja geopolityczna jest całkowicie odmienna. Jedna z popularnych polskich wokalistek, budząca liczne kontrowersje Maria Peszek, w swojej piosence „Sorry Polsko” wykłada inną wizję patriotyzmu:

Płacę abonament i za bilet płacę. Chodzę na wybory, nie jeżdżę na gapę. Tylko nie każ mi umierać. Tylko nie każ, nie każ mi. Nie każ walczyć, nie każ ginąć. Nie chciej, Polsko, mojej krwi.

0 tyle, o ile chodzenie na wybory zdaniem $80 \%$ jest przejawem patriotyzmu, tak pozostałe zachowania, o których śpiewa Peszek, nie spotykają się z tak powszechną aprobatą badanych. Poniżej 50\% zgadza się z twierdzeniem, że patriotyzm polega na płaceniu podatków $(48 \%)$ i płaceniu za bilety autobusowe $(42 \%)$.

$\mathrm{Za}$ to istnieje znacznie większa aprobata dla rozumienia patriotyzmu jako działalności na rzecz społeczności lokalnej (70\% badanych zgadza się lub zdecydowanie zgadza się). Jeszcze większy odsetek badanych (prawie 80\%) zgadza się z twierdzeniem, że patriotyzm polega na dbaniu o czystość $\mathbf{w}$ przestrzeni publicznej. Wynik ten w kontekście debat o zagrożeniach ekologicznych i zmianach klimatycznych może cieszyć. Z drugiej strony jednak sama obserwacja czystości w przestrzeni publicznej prowadzi do refleksji o nieadekwatności deklaracji badanej młodzieży do rzeczywistości.

Znany historyk Norman Davies zauważał, że:

patriotyzmem jest poczucie, że się należy do narodu, jest się za niego odpowiedzialnym, ale posiada się też prawo do krytykowania, proponowania zmian, 
Błażej Przybylski - Oblicza patriotyzmu. Kilka uwag...

prowokowania do dyskusji. Natomiast fałszywym patriotyzmem jest postawa nieuznająca obcych i bezkrytyczna w stosunku do ojczyzny ${ }^{11}$.

Nieco poniżej połowy badanych (47\%) zgadza się z twierdzeniem, że patriotyzm polega na krytycznym spojrzeniu na własny naród i jego historię. Prawo do krytyki oraz krytyczne spojrzenie na własny naród, jego historię czy teraźniejszość w ostatnich latach i miesiącach jest stosunkowo głośno dyskutowane. Pod adresem tych, którzy krytykują Polskę poza granicami kraju, padają oskarżenia o zdradę i targowicę. Podobne oskarżenia kierowane są pod adresem tych, którzy naukowo zajmują się badaniem historii, w tym niechlubnymi wydarzeniami z udziałem Polaków.

W kontekście aktualnych sporów politycznych ważny wydaje się stosunek badanych do zagadnienia praworządności. Istnieje powszechna zgoda, że patriotyzm polega też na poszanowaniu i przestrzeganiu prawa. Jedynie co 10 badany nie zgadza się z tym sformułowaniem. Także musi cieszyć rozkład odpowiedzi pojawiających się przy „szacunku do innych narodów". Tylko $6 \%$ badanych nie zgadza się, że jest on przejawem patriotyzmu (przy prawie 90\% zgadzających się z tym twierdzeniem). Jakże często jednak w przestrzeni publicznej patriotyzm mylony bywa z szowinizmem i nacjonalizmem.

W ostatnich latach modne stało się hasło patriotyzmu ekonomicznego, który - w skrócie mówiąc - oznacza podejmowanie decyzji, kierując się ich wpływem na losy kraju. Często bywa to utożsamiane ze „wspieraniem polskiego biznesu (np. chodzeniem na polskie filmy czy kupowaniem polskich produktów)". Z takim postrzeganiem patriotyzmu zgadza się mniej niż 50\% badanych. Jeszcze mniej, bo tylko $13 \%$ uważa, że patriotyzm polega na spędzaniu wakacji w Polsce. Najmniejszym poziomem aprobaty spośród wszystkich podanych form patriotyzmu cieszyła się odpowiedź „noszenie ubrań podkreślających dumę $\mathbf{z}$ bycia Polakiem". Tzw. odzież patriotyczna stała się w ostat-

${ }^{11}$ N. Davies, Można być patriota polskim i europejskim - w tym nie ma konfliktu interesów (wywiad). Źródło: https://natemat.pl/124789,norman-davies-mozna-bycpatriota-polskim-i-europejskim-w-tym-nie-ma-konfliktu-interesow [dostęp: 21-052019]. 


\section{nich latach stosunkowo popularna, szczególnie wśród osób o prawico- wych poglądach.}

\section{Wykres 1. Stopień akceptacji różnych form patriotyzmu}

Okazywaniu szacunku godłu, fladze i hymnowi... Pielęgnowaniu polskich tradycji Dbaniu o kulturę polską Dbałości o wychowanie dzieci Poszanowaniu i przestrzeganiu prawa Szacunku do innych narodów Udziale w wyborach

Dbaniu o czystość w przestrzeni publicznej Gotowość do walki i oddania życia za ojczyznę Kibicowaniu polskim sportowcom Wypełnianiu obowiązków zawodowych Odbywanie służby wojskowej Podejmowanie działań na rzecz społeczności.. Płaceniu podatków Płaceniu za bilety

Wspieraniu polskiego biznesu Krytycznym spojrzeniu na własny naród i jego... Spędzaniu wakacji w Polsce Noszenie ubrań podkreślających dumę z bycia..

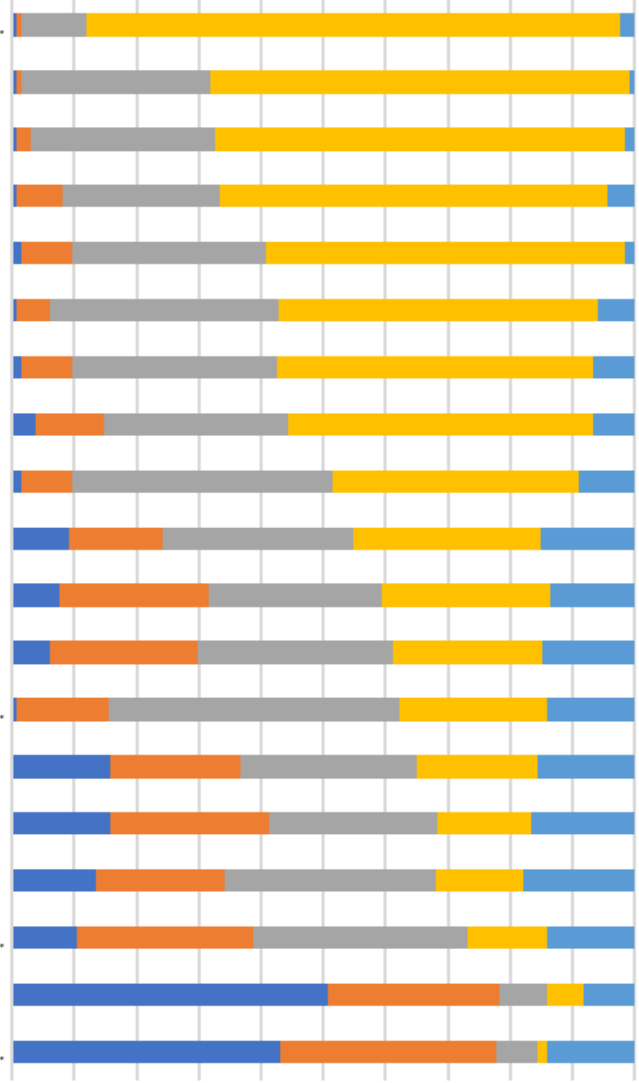

0\% 10\% 20\% 30\% 40\% 50\% 60\% 70\% 80\% 90\% 100\%

- zdecydowanie nie zgadzam się - raczej nie zgadzam się

- raczej zgadzam się ndecydowanie zgadzam się

- trudno powiedzieć

Źródło: badania własne. 
Błażej Przybylski - Oblicza patriotyzmu. Kilka uwag...

Badani zostali również poproszeni o odpowiedź na pytanie, co sądzą o patriotyzmie we współczesnym świecie. Ponad połowa (53\%) uważa, że jest on nadal ważny i aktualny, ale ma on inną formę niż kiedyś. Ponad 40\% sądzi, że patriotyzm w dzisiejszych czasach stracił na znaczeniu. Jedynie 3\% wskazało, że jest wartością niezmienną i nieprzemijającą. Nikt z badanych nie wybrał odpowiedzi: „patriotyzm jest dziś kompletnie nie na miejscu". Jak widać, zróżnicowanie poglądów na temat patriotyzmu we współczesnym świecie wskazuje na konieczność przedefiniowania znaczenia patriotyzmu - tak, aby nie był on wyłącznie kojarzony z minionymi epokami i koniecznością podejmowania walki w obronie ojczyzny.

Polacy, co pokazują najnowsze badania na reprezentatywnej próbie, w zdecydowanej większości uważają sami siebie za patriotów. Wśród młodych osób jest to dość rozpowszechniona postawa - zadeklarowało ją ponad dwie trzecie (67\%) badanych uczniów. W większym stopniu ludzie starsi deklarują, że są patriotami - wśród ogółu mieszkańców Polski odsetek ten wynosi $88 \%{ }^{12}$. Mnie także interesowała autoidentyfikacja badanych z patriotyzmem. Zdecydowana większość badanych studentów (80\%) uważa się za patriotów. Ponad 2/3 badanych zaznaczyło odpowiedź „raczej tak”, a co 10 wybrał, że „zdecydowanie uważa się za patriotę". Mniej niż 8\% nie uważa się za patriotę. Odsetek takich osób jest znacznie mniejszy niż wśród ogółu młodzieży - badania CBOS pokazują, że systematycznie on rośnie i wynosi już $23 \% 13$.

\section{Podsumowanie}

W zrealizowanym badaniu interesowały mnie współcześnie akceptowane przez młodzież akademicką formy patriotyzmu. Badanie miało charakter deklaratywny - z całą pewnością należy prowadzić pogłębione badania nad znaczeniami nadawanymi patriotyzmowi przez młodych, ale także uważnie i systematycznie przyglądać się, kto, w jaki

\footnotetext{
12 M. Grabowska, [w:] M. Gwiazda (red.), Młodzież 2018, Warszawa 2019, s. 128.

13 Ibidem.
} 
sposób i w jakim stopniu kształtuje nasze postawy względem ojczyzny. Badanie było realizowane dwa lata temu. W czasach gwałtownych zmian społeczno-politycznych postrzeganie patriotyzmu przez młodych ludzi mogło ulec zdecydowanym zmianom. Dziś w mediach coraz częściej słyszymy głosy o przejściu z systemu demokratycznego do autorytarnego czy też o wzrastających zagrożeniach związanych ze zmianami klimatu. Takie formy patriotyzmu, jak przestrzeganie prawa czy dbanie o środowisko i czystość w przestrzeni publicznej, być może, stają się dominującymi obliczami dzisiejszego patriotyzmu.

Na podstawie wyników ankiety można pokusić się o tezę o zróżnicowanych obliczach patriotyzmu, tożsamą z obserwacjami chociażby Marcina Króla, który pisał: „w nowoczesnych społeczeństwach liberalnych nie doszło do zaniku patriotyzmu, jak to się często sądzi, lecz do jego pluralizacji"14. W Polsce widoczna nadal jest dominacja myślenia o patriotyzmie w kategoriach symbolicznych, związanych z kultywowaniem pamięci, tradycji, kultury. Ponadto kluczowym pytaniem pozostaje nie tylko to o treść, sens i znaczenie patriotyzmu wśród młodych obywateli, ale i o kierunek ich rzeczywistego i potencjalnego zaangażowania w budowanie przyszłości kraju, w którym przyszło im żyć. Jedną z cech charakterystycznych zachodniego świata jest pluralizm na wielu płaszczyznach życia wspólnotowego. Ten pluralizm odnotowujemy także w myśleniu o patriotyzmie. Jeszcze szerzej, same zagadnienie zróżnicowania młodzieżowych postaw wobec ojczyzny można by potraktować w sposób znacznie pełniejszy i wnikliwszy. Piszący współcześnie o patriotyzmie podkreślają jego liczne wypaczenia oraz schorzenia. Jedną z głównych chorób stanowi nacjonalizm, który „szkodzi patriotyzmowi, nie tylko tak jak szkodzi każdy pasożyt, ale także w inny sposób"15.

14 M. Król, Patriotyzm przyszłości..., op. cit., s. 112.

15 Ibidem, s. 33. 
Błażej Przybylski - Oblicza patriotyzmu. Kilka uwag...

\section{Bibliografia:}

Bartoszewski W., Patriotyzm czasu wojny i pokoju, [w:] A. Kozłowska (red.), Patriotyzm polski jaki jest? Jaki winien być?, Światowy Związek Żołnierzy Armii Krajowej: Oficyna Wydawnicza RYTM, Warszawa 2001.

Davies N., Można być patriotą polskim i europejskim - w tym nie ma konfliktu interesów, 2014, https://natemat.pl/124789,norman-davies-mozna-bycpatriota-polskim-i-europejskim-w-tym-nie-ma-konfliktu-interesow [dostęp: 21-05-2019].

Grabowska M., [w:] M. Gwiazda (red.), Młodzież 2018, Wyd. CBOS, Warszawa 2019.

Król M., Patriotyzm przyszłości, Wyd. Rosner i Wspólnicy, Warszawa 2004.

Kwieciński Z., Edukacja wobec wyzwań demokracji, [w:] Z. Kwieciński, Tropyślady - próby, Wydawnictwo Edytor, Poznań-Toruń 2000.

Lipski J.J., Dwie ojczyzny, dwa patriotyzmy. Rzecz o megalomanii narodowej i ksenofobii Polaków, Wydawnictwo PEN, Warszawa 1992, http://otwarta. org/wp-content/uploads/2011/11/J-Lipski-Dwie-ojczyzny-dwapatriotyzmy-lekkie3.pdf.

Szymański M.J., Socjologia edukacji. Zarys problematyki, Oficyna Wydawnicza „Impuls”, Kraków 2013.

White J., Patriotism without Obligations, „Journal of Philosophy of Education” 2001, nr 1 (35), s. 141-151.

Zembylas M., The Teaching of Patriotism and Human Rights: An uneasy entanglement and the contribution of critical pedagogy, „Educational Philosophy and Theory", 2014 nr 10 (46), s. 1143-1159. 